\title{
Performance and Improvement of Production Line Function Using Computer Simulation (Case Study: An Iron Foundry)
}

\author{
Alireza Abedi Saidabad, Houshang Taghizadeh* \\ Department of Management, Tabriz Branch, Islamic Azad University, Tabriz, Iran \\ Email: Alireza.abedi68@yahoo.com, "Taghizadeh@iaut.ac.ir
}

Received 19 September 2015; accepted 8 December 2015; published 11 December 2015

Copyright $@ 2015$ by authors and Scientific Research Publishing Inc.

This work is licensed under the Creative Commons Attribution International License (CC BY). http://creativecommons.org/licenses/by/4.0/

(c) (i) Open Access

\begin{abstract}
Using the accurate methods and tools for evaluation of function in different areas is of great importance. In recent years, much more studies have been done on the nature and methodology of function evaluation in organizations and its improvement. This study aimed to evaluate and improve the function of production line through computer simulation in one of the iron foundries in Iran. For this purpose, at first data has been gathered on the basis of timing with chronometer for each one of the production line machineries and using this data, distribution functions governing the activity cycle of each one of these machineries have been determined; and then, using the required gathered data for computer simulation (taking the advantage of "ED" simulation software), a model was simulated to introduce the current situation of production line and the validity of simulated model was measured on the basis of production rate. And then, considering the criteria such as the production rate, average waiting time, machine utilization coefficient, production yield, production cost, production income and the production time production line function was evaluated. Finally, applying amendment changes on the simulated model improved model was offered.
\end{abstract}

\section{Keywords}

Simulation, Function Evaluation, Function Improvement

\section{Introduction}

As a powerful tool for analyzing complex stochastic systems, computer simulation has been commonly used in a wide spectrum of fields including but not limited to healthcare [1], marketing [2], supply chain [3], and military

\footnotetext{
${ }^{*}$ Corresponding author.
}

How to cite this paper: Saidabad, A.A. and Taghizadeh, H. (2015) Performance and Improvement of Production Line Function Using Computer Simulation (Case Study: An Iron Foundry). American Journal of Computational Mathematics, 5, 431446. http://dx.doi.org/10.4236/ajcm.2015.54038 
[4]. In particular, simulation has played a significant role in evaluating the design and operational performance of manufacturing systems. Successful applications of simulation in many practical real-world problems have proved its effectiveness in approaching various problems in the manufacturing sector.

The general topic of simulation and the use of different simulation software have been addressed in several books (see, Kelton et al. [5] [6], Law [7], Banks et al. [8], Ross [9]). Several publications have also discussed different aspects of simulation modeling including verification and validation of models, and conducting and analyzing simulation experiments (for example, Law [10] [11], Robinson [12], Fischbein and Yellig [13], Baines et al. [14]).

The category of function evaluation is paying attention to "must" and "is". It is through evaluation that one can attain the gap between function and purpose. In today's competitive world, the only condition for survival and participation in various activities, is rectitude and enjoying efficiency and effectiveness and these cannot be reached unless by ongoing planning, monitoring, control and evaluation of [15].

Using computer simulation, one can compress the time so that activities of several years be simulated during a few minutes and sometimes during a few seconds. Using this concession, analyst can implement various designs about the real issue in no time and evaluate them [16].

This plant is to increase its production rate but in order to achieve this goal, different factors inside and outside the system prevent it. Factors outside the system are not under the control of the plant but factors inside the system are. That's why the company seeks to improve and control the internal factors of the system.

Therefore, the situation of production line function and improvement in this iron foundry, using the computer simulation is the main problem of this research. In this research production line of the round bar of this plantwhich is its main part-has been evaluated.

The outline of this paper is as follows: In Section 2, the theoretical foundations and background of the research has been studied. In Section 3, methodology of the research has been described. In Section 4, findings obtained from the research have been analyzed. Finally, Section 5 includes conclusion and proposals.

\section{Theoretical Foundations}

\subsection{Background of the Research}

Pinto et al. [17], a generic method to develop simulation models for ambulance systems. In this paper, address the question of generic simulation models and their role in improving emergency care around the world. Mourtzis et al. [18], simulation in Manufacturing: Review and Challenges. This paper investigates the evolution, advances, current practices and future trends of simulation methods and tools. Ruiz et al. [19], an intelligent simulation environment for manufacturing systems. In this paper, an Agent-supported Simulation Environment for intelligent manufacturing systems is presented. Zhang [20] investigating the impact of operational variables on manufacturing cost by simulation optimization. Using a relatively new simulation package called $\mathrm{Simio}^{\mathrm{TM}}$, Chongwatpol and Sharda [21] develop simulation models to examine the benefits of an information visibility-based scheduling rule for job shop manufacturing systems that is based on RFID traceability. Roux et al. [22] study the optimization of multi-component preventive maintenance problems. They develop a generic and easyto-understand modeling tool for simulation in order to facilitate the optimization of production and maintenance. Melouk et al. [23] propose a simulation optimization-based decision support system for steel manufacturing where an optimizer, OptQuest ${ }^{\mathrm{TM}}$, sends potentially beneficial process modifications a simulation model to investigate their performance of the system. Through a case study of TFT-LCD manufacturing system, Huang et al. [24] develop a simulation model to solve the re-scheduling problems in flow shop mixed-lines. Using computer simulation, Altuntas and Selim [25] evaluate and compare several new weighted association rule-based data mining approaches for facility layout problem. Amiri and Mohtashami [26] relax the typical restriction of having deterministic or exponentially distributed processing times, time between failures, and repair times and propose a simulation-based methodology for buffer allocation in production lines. Huang et al. [27] develop a simulation model of a real world fab and use a simulation optimization technique to obtain the optimal vehicle allocation. Through a simplified simulation model of a pipe manufacturing capacity, Dong and Medeiros [28], aim to minimize cost of batch schedules considering material holding cost, late delivery cost, and changeovers. Ehrenberg and Zimmermann [29] present a simulation-based scheduling approach for make-to-order production systems and evaluate its applicability in a real-world case study of a special-purpose glass manufacturer. In their approach, mixed-integer programming is used to generate schedules while its input parameters and constraints 
are iteratively updated by a simulation model. To address the sblock assembly scheduling in shipyard production and by considering spatial optimization, Zhuo et al. [30] employ discrete event simulation to evaluate and improve system performance. Through a scalable production planning simulation model, Felberbauer et al. [31] study the performance of two different machine allocation (i.e., segmentation) policies in a combined MRP and Kanban production system. Through a case study, Mahfouz et al. [32] integrate simulation with optimization techniques to evaluate the implementation of lean principles in small and medium enterprises (SMEs) with regards to three performance measures, namely cycle time, WIP, and workforce utilization. Angelidis et al. [33] introduce a generic simulator incorporating realistic schedules, priority rules, and resource restrictions designed specifically for the simulation of complex assembly lines. Porzucek et al. [34] use an analytical performance prediction approach to improve the performance of discrete event simulation. They evaluated their method based on an industrial case study. Mahdavi et al. [35] development of a simulation-based decision support system for controlling stochastic flexible job shop manufacturing systems. Savory and Williams [36] describe a discreteevent simulation model of a U-shaped manufacturing cell and the integration of it with activity-based costing (ABC) concepts cost estimation and analysis of the manufacturing cell design. Vasudevan et al. [37] describe the application of simulation along with bottleneck analysis, work measurement, floor space requirements and facility layout analysis to increase reliability and profitability of steel-mill manufacturing. Jithavech and Krishnan [38] present a simulation-based method to develop an efficient facility layout design under uncertainty in the product demand. They quantify the impact of stochastic demand in terms of risk and show that their method can significantly reduce the risk associated with the layout. Edis and Ornek [39] Simulation analysis of lot streaming in job shops with transportation queue disciplines. An effective approach for improving performance of a manufacturing shop is to develop a simulation model that meets the desired objectives. Um et al. [40] present a hybrid method that combines simulation-based analytical and optimization techniques for an FMS with AGV systems to satisfy three objectives of minimizing congestion, maximizing vehicle utilization, and maximizing the throughput. Nandagawe and Sarmah [41] use a simulation model to identify bottlenecks of a steel melting plant in order to find the optimum casting plan horizon. Alfieri [42] studies a multiple objective flow shop scheduling problem in a cardboard company with multi-machine stations and sequence-dependent setup times. They present a simulation-based environment in which the production sequence is interactively chosen by a tabu search based heuristic algorithm while a discrete-event simulation deals with the timing aspect. Greasley [43] develops a simulation model to estimate the storage area required for a textile manufacturing facility. Habchi and Berchet [44] a model for manufacturing systems simulation with a control dimension. The objective of this article is related to the potential improvement of computer simulation as applied to manufacturing systems.

In a research titled "optimization of function of the production system of fire clay of Abadeh on the basis of simulation" Saber Alamdari [45] has analyzed the system function and after developing it he has studied the increase potential of production with active machineries in the mine as well as the costs of production unit. Applying the flexible allocation method of the trucks, he has also studied the effect of applying this method on production and production costs of the system. In a research titled "Improvement of the daily production rate of a snack production line, using the two strategies of simulation and genetic algorithms" Meysam Shahrestani [46] has presented the best answer which has the most amount of production, the least amount of waiting time and the least amount of costs to the plant for the optimized model of production. In a research titled "using the strategy of discrete event simulation in reducing the average waiting time of the costumers in queues (case study of Hyper Star Iran Shop)" Mohsen Adl [47] has presented the best possible strategies to managers for the purpose of appropriate decision makings.

The application of Simulation for optimization have been illustrated in case studies of an engine manufacturing line [48], flow shop [49], job shop [50], dedicated remanufacturing [51], FMS [52], parallel machine scheduling [53], and multi-constant work-in-process problem [54]. Several other studies use simulation to assess the performance of real-time control systems in assembly lines Gong et al. [55], Wu et al. [56], flow shops [57] [58], and job shops [59], and semiconductor manufacturing [60]. For list of other studies that use simulation to evaluate the performance of different scheduling rules, see [61]-[66].

\subsection{Concepts and Definitions}

\subsubsection{Production Line and Making It Balanced}

Production line is a regular deployment of workstations that have regularly and continuously been located beside 
each other and materials are uniformly flowing along them on a reasonable path.

In order to deal with the issue of balancing the production lines we need the following information:

1) Production volume.

2) List of operations and their orders and sequences.

3) The time required to complete each operation [67].

\subsubsection{Principles of Production Line}

Production line has seven principles which are as follows:

1) The principle of least distance: work stations should be located to the minimum distance to each other.

2) The principle of constant flow: materials must flow continuously and with fixed rate.

3) The principle of the division of labor between the staff of the line: circulation and division of labor between individuals.

4) The principle of concurrency of the operations: in a production line all people should be working (on the first, last and all parts of the line).

5) The principle of entirety of the operations: the entire set must be considered as a unit and with an overall goal.

6) The principle of least time: finding the minimum time among the times.

7) The principle of the ability to internal exchange: displacement of the persons [67].

\subsubsection{An Introduction to Simulation}

Simulation is an imitation of performance of the real process or system over the time. Regardless of the fact that simulation is done manually or by computer, it relates to the fictitious creation of history of the system and its revision for the purpose of reaching some conclusions about the features of real system function.

As a system will be developed over the time, its behavior is studied by creating the simulation model. This model is usually in the form of a set of assumptions related to the system's performance. These assumptions are expressed in the framework of mathematical, logical and symbolic relations among the institutions or intended purposes of the system. Due to the creation and validation of the model, it can be used to investigate various questions about the real system such as "What will happen if?” In order to predict the effects of possible changes on performance, those changed can initially be simulated. Simulation for the purpose of studying the systems under designing is also applicable prior to their creations.

The availability of languages that are specific to simulation, extensive computational capabilities together with decreasing costs of any computation, and advances in simulation techniques, have caused this topic to be considered as one of the most common and most widely accepted in research tools in systems' operations and analysis [16].

\subsubsection{Advantages and Disadvantages of Simulation}

Although simulation is an appropriate tool for analysis in many cases, before applying this method in any case, analyst of the system should consider its advantages and disadvantages.

The main advantages of simulation, which Schmidt and Taylor and others have discussed about, are as follows:

1) After building the mode it is possible to use it frequently in order for analysis of the plans or the proposed polies.

2) Simulation techniques can be used to assist the analysis of any proposed system, even if the input data is approximate and imperfect.

3) Usually access to simulation data is associated with much less costs than providing the data, related to the real system.

4) Making use of simulation techniques is usually easier than analytical methods. Therefore, the number of potential users of simulation techniques is much greater than the analytical methods.

5) Through using analytical models, analyst can usually measure only a limited number of measurement criteria of the system performance, while data generated from simulation models is applicable to estimate any expected criterion of performance measurement.

6) In some cases the only means of finding a solution to the problem is simulated.

Schmidt and Taylor have also presented the list of disadvantages of simulation that should be considered be- 
fore its deployment:

1) The simulation models of digital computers may be costly, because their construction and validation require significant time.

2) We usually need many performances of the any simulation model and this very issue may lead to large fees for the use of computer.

3) Sometimes simulation is used in situations where analytical methods seem to be enough. This situation arises in cases where users become familiar with simulation method and forget their taught mathematics [16].

\section{Tools and Methods}

Research methods: on the basis of objective, the present research is considered as "applied research".

Statistical society: statistical society includes all machineries that are related to the round-bar production line which has 13 main appliances; and upon them timing has been done.

Sample size: in order to determine the sample volume for timing on each one of the machineries of production line the following relation has been used [68].

$$
n \geq\left(\frac{Z_{\frac{\alpha}{2}} \cdot \sigma_{0}}{\varepsilon}\right)^{2}
$$

Considering $\alpha=0.05$ and $\varepsilon=0.3$, the number of timing for the whole machineries of production line was estimated as: $n=727$. Each timing process has taken place 20 minutes after the previous one; and totally, information obtained from timing processes was gathered in 3 months.

Data collection methods: this research has made use of library and internet studies to prepare and compile its theoretical foundations and backgrounds; and for the timing (with chronometer) purposes on machineries, it has taken the advantage of observation.

Data collection tools: sheets of gathering information for machineries timing are data gathering tools in this research; and its information has been gathered using the timing by chronometer.

Analysis method of the gathered data: analysis methods used in this paper are as follows:

- Determining the type of distribution functions governing the cycle activities of machineries using Easy Fit software.

- Constructing simulation model for the current status of the production line and improved model using ED software.

- Determining the validity of model using Student-T-test.

\section{Findings Obtained from the Research}

\subsection{Simulation of Real Model}

Using the gathered data which is required for simulation software, results obtained from "Easy Fit" software (Tables B1-B13), transposition diagram (Figure 1) according to the numbering the machineries (Table 1), and finally taking the advantage of computer simulation by "ED" software, deployment model of sections and machineries of round-bar production line in the current status were simulated in the form of Figure 2 (summary report in Table A1).

\subsection{Validation of Simulation Models}

After creating a simulation model and before applying corrective changes on it we should know whether simulation model represents the actual system or not?

To further ensure the validity of the simulation model statistical tests should be used; and in this research Student-T-test was used [68]. In order to determine the validity of the model, the amount of production was chosen as measurement criterion; and if the average value of production in reality is equal to the value of simulated production line, then the validity of simulated model will be confirmed. For this purpose, the amount of imported product to the warehouse in 10 shifts was recorded and also, the simulated model was implemented ten times, its production rate were recorded, and finally the following results (Table 2) were obtained: 


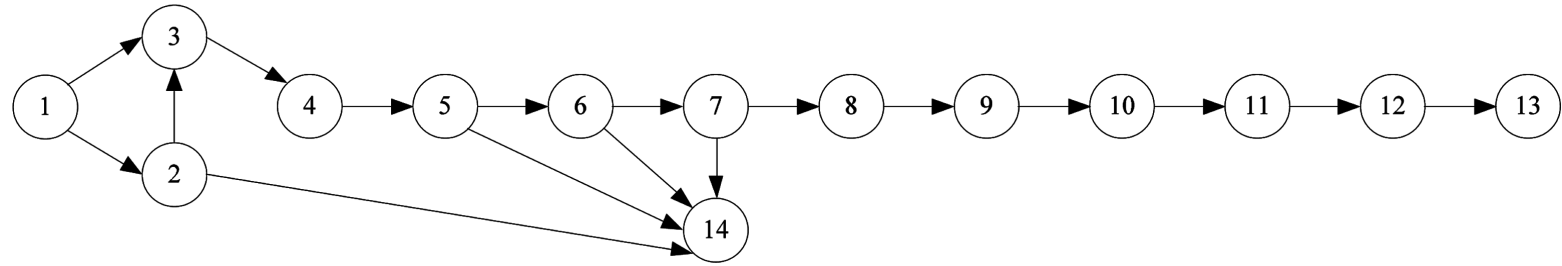

Figure 1. Transposition diagram.

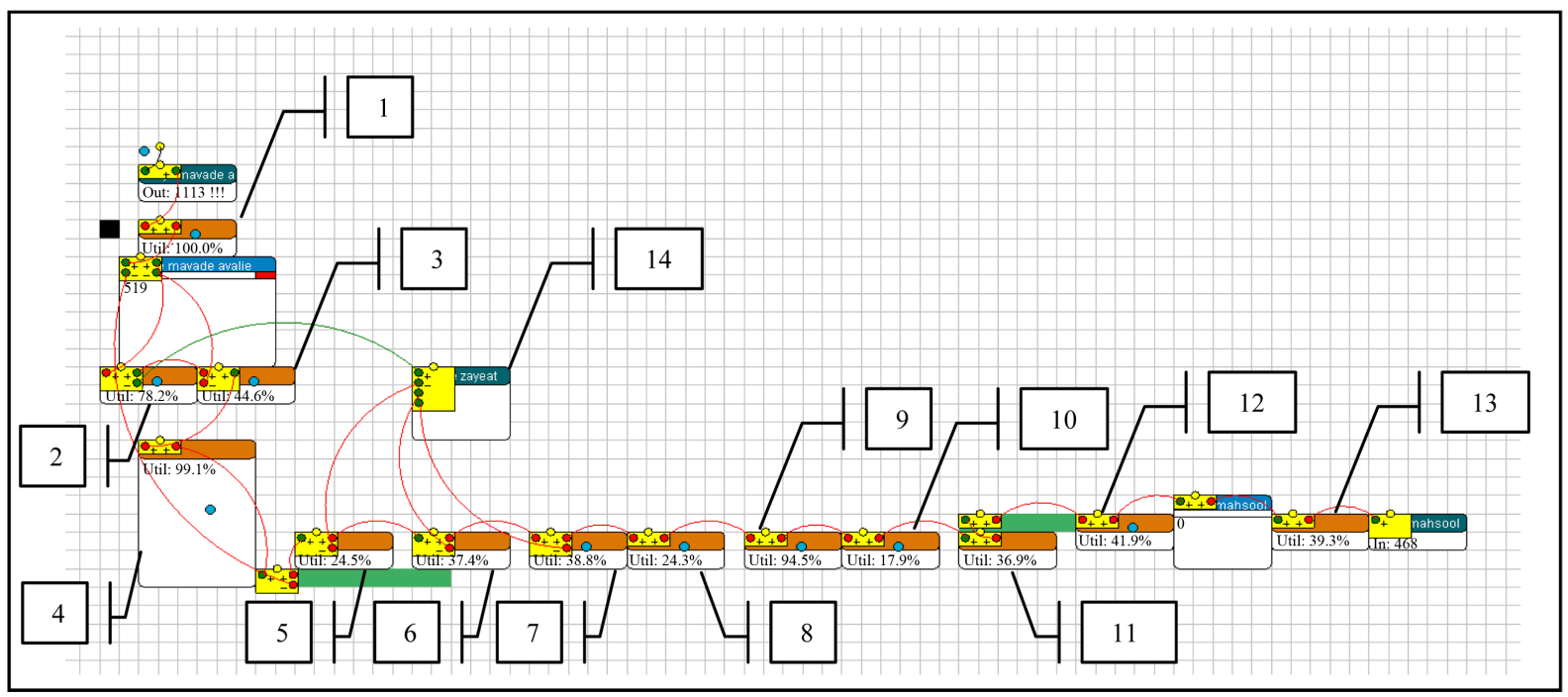

Figure 2. Simulation model of the current situation of production line.

Table 1. Numbering the machineries.

\begin{tabular}{cccc}
\hline No. & Machinery Name & No. & Machinery Name \\
\hline 1 & Overhead Crane (No. 1) (Capacity 10 tons) & 8 & Overhead Crane (No. 3) (capacity 16 tons) \\
2 & Bullion Shearing machine & 9 & Cooling bed \\
3 & Overhead Crane No. 2 (Capacity 10 tons) & 10 & Electric Cold Use scissors \\
4 & Furnace (3 steps) & 11 & Packing \\
5 & Rolling (step 1) & 12 & Overhead Crane (No. 4) (capacity 10 tons) \\
6 & Rolling (step 2) & 13 & Overhead Crane (No. 5) (capacity 10 tons) \\
7 & Rolling (step 3) & 14 & Waste storage \\
\hline
\end{tabular}

Table 2. Statistical data (average, variance, number of samples).

\begin{tabular}{cc}
\hline Real system & Simulated model \\
\hline $\bar{x}_{1}=464.5$ & $\bar{x}_{2}=470.4$ \\
$S_{1}^{2}=56.278$ & $S_{1}^{2}=37.822$ \\
$n_{1}=10$ & $n_{2}=10$ \\
\hline
\end{tabular}

Before comparison test among the averages it should be known whether the two societies have the same variance or not. Therefore, for the purpose of comparing the variances of the two societies, initially statistical hypothesis testing should be done.

Hypothesis zero, and hypothesis one were defined on the basis of equality of variances of the two societies, 
and lack of variance equality of the two societies with confidence level of 95\%, respectively:

$$
\begin{gathered}
\left\{\begin{array}{l}
H_{0}: \sigma_{1}^{2}=\sigma_{2}^{2} \\
H_{1}: \sigma_{1}^{2} \neq \sigma_{2}^{2}
\end{array}\right. \\
1-\alpha=0.95 \Rightarrow 1-\frac{\alpha}{2}=0.975 \\
F=\frac{S_{1}^{2}}{S_{2}^{2}}=1.48
\end{gathered}
$$

According to distribution table $F, F_{0.975,9,9}=4.03$, and since $1.48<4.03$ and it is placed on $H_{0}$ district, therefore $H_{0}$ assumption is accepted at confidence level of $95 \%$.

Now it is time to do the comparison tests of the two statistical societies for real and simulated models. For this purpose, a mode has been selected in which standard deviations of two societies are unknown but equal to each other. This test has also been done at confidence level of 95\%; and since freedom degree is less than 30, the distribution of statistical sampling is Student-T-test.

$$
\begin{gathered}
\left\{\begin{array}{l}
H_{0}: \mu_{1}=\mu_{2} \\
H_{1}: \mu_{1} \neq \mu_{2}
\end{array}\right. \\
S_{p}=\sqrt{\frac{\left(n_{1}-1\right) S_{1}^{2}+\left(n_{2}-1\right) S_{2}^{2}}{n_{1}+n_{2}-2}}=6.859 \\
t=\frac{\left(\bar{X}_{1}-\bar{X}_{2}\right)-\left(\mu_{1}-\mu_{2}\right)}{S_{p} \sqrt{\left(\frac{1}{n_{1}}+\frac{1}{n_{2}}\right)}}=-1.92
\end{gathered}
$$

Using the $\mathrm{t}$ distribution table, $t_{0.025,18}= \pm 2.101$ and since $t=-1.92$, it is located on $\mathrm{H}_{0}$ district. Therefore, assumption $\mathrm{H}_{0}$ is accepted at confidence level of $95 \%$ and the average of the two societies are equal to each other. In other words, the assumption of the equality of the two averages of the two statistical societies obtained from the real performance and simulated model are confirmed and simulated model is authentic.

\subsection{Simulation of Improved Model}

In this research performance of production line has been improved by creating corrective changes in the operations and activity times of machineries, adding some departments, balancing the production line, increasing the utilization coefficient of machineries, reducing the average waiting time of machineries, and identifying bottlenecks and eliminating them. In detailed and precise mode, these changes are as follows:

Changes in time and space of eating meals, using the timing information, cycle time of some machinery that had a lot of waste of time was changed from compliance of the distribution function into standard time, making use of the strategies such as Preventive maintenances, empowering the manpower and also increasing employees' accuracy in order to reduce the rate of wastes and withdrawal time of these wastes from production line, adding intermediate depot prior to furnace section in order to increase utilization of machineries of this section, adding the new cooling bed in parallel with present cooling bed in order to eliminate the bottleneck.

After making the above changes, the improved model was prepared and compiled as shown in Figure 3 (summary report in Table A2).

\subsection{Evaluation of Performance of Simulated Models}

After running the model of status quo and that of improved model, performance evaluation took place according to the following indexes:

Amount of production: in order to evaluate and measure the amount of production, results obtained from simulation software have been used (in terms of tons). 


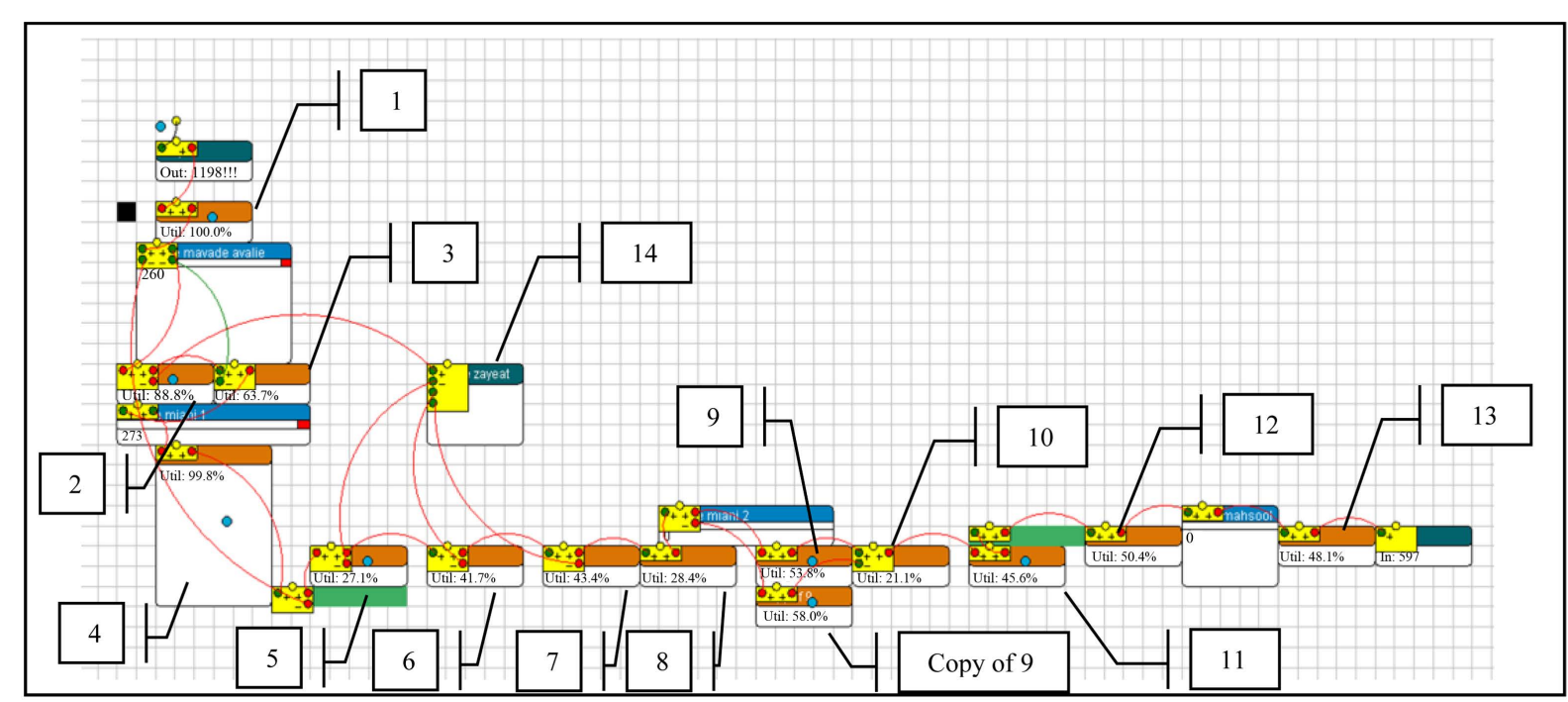

Figure 3. Model of improved simulation of production line.

Average waiting time: in order to evaluate and measure the average waiting time results obtained from simulation software and the total of average waiting time of the machineries have been used (in terms of seconds).

Utilization coefficient of machineries: in order to evaluate and measure the utilization coefficient of machineries, results obtained from simulation software and the average of utilization coefficient of the whole machineries have been used.

Production yield: in order to evaluate and measure production yield, results obtained from simulation software and the following relation [69] have been used (in terms of tons).

$$
Y=(I)(\% G)+(I)(1-\% G)(\% R)
$$

Y: Yield.

I: The number of programmed production, since the beginning time of production process.

$\% G$ : percentage of produced goods.

$\% R$ : percentage of defective goods which have been renovated.

Production cost: in order to evaluate and measure production cost, results obtained from simulation software and the following relation [69] have been used (in terms of Iranian Rial):

$$
\begin{aligned}
& {[(\text { the number of daily production }) \times(\text { direct cost of production })] } \\
& \text { Production cost }=\frac{+[(\text { maintenance cost }) \times(\text { defected units })]}{\text { Yield }}
\end{aligned}
$$

Production income: in order to evaluate and measure the income, results obtained from simulation software and the following relation have been used (in terms of Iranian Rial)

$$
\text { Income }=\text { the price of each product } \times \text { the amount }
$$

This income has been calculated on the basis of sales price in iron selling agencies; and by subtracting the cost price of producing the row materials the production income of production line of round bar of this plant is calculated.

Production time: in order to evaluate and measure the production time, results obtained from simulation software have been used. In fact, the production cycle of one unit of the product (one ton) has been calculated which has been obtained by dividing the time amount by production rate in one work shift (in terms of second).

After calculating each one of these indexes for the model of current status and improved model, results were obtained according to the Table 3.

Comparing the model of current situation of production line and improved model is as follows:

1) Increase in the amount of production from 468 tons to 597 tons in a work shift. 
Table 3. Results obtained from simulated models.

\begin{tabular}{ccc}
\hline Indexes & \multicolumn{2}{c}{ Models } \\
Production rate & Status quo model & Improved model \\
\cline { 2 - 3 } Average waiting time & 468 & 597 \\
Utilization coefficient of machineries & 380.89 & 359.825 \\
Production efficiency & 0.521 & 0.5499 \\
Production cost & 472.129 & 598.556 \\
Production income & $934,772,826$ & $1,195,341,980$ \\
Production time & $8,083,636,362$ & $10,311,818,180$ \\
\hline
\end{tabular}

2) Reduction in average waiting time for all machineries of production line from 380.89 to 359.825.

3) Increase in average utilization coefficient of all machineries from $52.1 \%$ to $54.99 \%$ in a work shift.

4) Increase in the production yield from 472.129 tons to 598.556 tons in a work shift.

5) Increase in production cost from $934,772,826$ Rials to $1,195,341,980$ Rials in a work shift.

6) Increase in income from 8,083,636,362 Rials to 10,311,818,180 Rials in a work shift.

7) Reduction in production cycle of one ton product from 50 seconds to 42.21 seconds.

From among the abovementioned cases, the current model is in good condition only in production cost and this is due to increase in the amount of production. The rest of the indexes cover this case and decrease its effects.

\section{Conclusions and Proposals}

\subsection{Conclusions}

By comparing these two models, it can be concluded that in contrast to the current situation model, improved model is in a better status regarding the examined indicators. In the proposed model, production amount has had considerable increase. Average waiting time for machineries and production line has been decreased including: Bullion cutting machine, overhead crane 2 , rolling stage 1 , rolling stage 2 , rolling stage 3 , and overhead crane 3 . Increase in utilization of machineries such as: bullion cutting machine, overhead crane 2, rolling stage 1, rolling stage 2, rolling stage 3 , overhead crane 3 , electric cold use scissors, packing, overhead crane 4 , and overhead crane 5. Increase in production yield which is indicative of increase in production. Increase in production income has also taken place in a considerable amount and finally production time of one ton output has also been decreased in an appropriate amount.

In addition to the improvements discussed above, in the proposed model, the amount of non-reinventing wastes has been decreased from 117 tons to 61 tons. Some of the other cases of increase in helpful work hours from 6.5 hours to 7 hours per one work shift and also, decrease in the amount of reinventing on defective bullions up to $50 \%$ is among the helpful changes in the improved model. Therefore, the improved model is proposed to this factory to be used in practice.

In addition to the iron melting factory studied in this research, all of the manufacturing and service organizations can considerably reach the improvement in their organizations by using this method.

\subsection{Executive Suggestions}

- Displacement of having breakfast to the work place and changing the time of having lunch into the time after completion of the first work shift. This will cause increase in the work shift time.

- Using strategies such as preventive maintenances, empowering human resources through staff training and also increasing the accuracy of staff for the purpose of decreasing the wastes and the waste of time for its exit from production line.

- Creating an intermediate storage before furnace section. This action increases the utilization of machineries of loading section, cutting bullions, and the crane which carries bullions to the furnace. 
- Creating an intermediate storage before the cooling bed section. This will cause increase in utilization of rolling sections and overhead crane with the capacity of 16 tons. Installing a new cooling bed in parallel with the available cooling bed. Due to the adding this section in parallel with bottleneck, the amount of production will considerably be increased.

\subsection{Recommendations for Future Researches}

- Using more parameters in simulations in order to evaluate the exact performance of the models.

- Predicting the function of production line before construction using simulation.

- Simulation of production lines with probable times.

- Integration of simulation method with other methods for the purpose of doing the researches.

- Running a simulation on a longer time horizon.

- Making use of phase data in simulations.

\section{References}

[1] Mielczarek, B. and Uzialko-Mydlikowska, J. (2012) Application of Computer Simulation Modeling in the Health Care Sector: A Survey. Journal of Simulation, 88, 197-216. http://dx.doi.org/10.1177/0037549710387802

[2] Negahban, A. and Yilmaz, L. (2013) Agent-Based Simulation Applications in Marketing Research: An Integrated Review. Journal of Simulation, 8, 129-142. http://dx.doi.org/10.1057/jos.2013.21

[3] Terzi, S. and Cavalieri, S. (2004) Simulation in the Supply Chain Context: A Survey. Computers in Industry, 53, 3-16. http://dx.doi.org/10.1016/S0166-3615(03)00104-0

[4] Naseer, A., Eldabi, T. and Jahangirian, M. (2009) Cross-Sector Analysis of Simulation Methods: A Survey of Defense and Healthcare. Transforming Government: People, Process and Policy, 3, 181-189. http://dx.doi.org/10.1108/17506160910960568

[5] Kelton, W.D., Sadowski, R.P. and Swets, N.B. (2010) Simulation with Arena. 5th Edition, McGraw-Hill, Boston.

[6] Kelton, W.D., Smith, J.S., Sturrock, D.T. and Verbraeck, A. (2011) Simio and Simulation: Modeling, Analysis, Applications. McGraw-Hill Learning Solutions, Boston.

[7] Law, A.M. (2006) Simulation Modeling and Analysis. 4th Edition, McGraw-Hill, New York.

[8] Banks, J., Carson, J.S., Nelson, B.L. and Nicol, D.M. (2009) Discrete-Event System Simulation. 5th Edition, Prentice Hall, Upper Saddle River.

[9] Ross, S.M. (2006) Simulation. 4th Edition, Academic Press, Burlington.

[10] Law, A.M. (2005) How to Build Valid and Credible Simulation Models. Proceedings of the 2005 Winter Simulation Conference, 24-32. http://dx.doi.org/10.1109/WSC.2005.1574236

[11] Law, A.M. (2003) How to Conduct a Successful Simulation Study. Proceedings of the 2003 Winter Simulation Conference, 1, 66-70. http://dx.doi.org/10.1109/WSC.2003.1261409

[12] Robinson, S. (2006) Conceptual Modeling for Simulation: Issues and Research Requirements. Proceedings of the 2006 Winter Simulation Conference, Monterey, 3-6 December 2006, 792-800. http://dx.doi.org/10.1109/WSC.2006.323160

[13] Fischbein, S.A. and Yellig, E. (2011) Why Is It So Hard to Build and Validate Discrete Event Simulation Models of Manufacturing Facilities? In: Kempf, K.G., Keskinocak, P., Uzsoy, R., Eds., Planning Production and Inventories in the Extended Enterprise, International Series in Operations Research \& Management Science, Vol. 152, SpringerVerlag, New York, 271-288. http://dx.doi.org/10.1007/978-1-4419-8191-2_12

[14] Baines, T., Mason, S., Siebers, P.O. and Ladbrook, J. (2004) Humans: The Missing Link in Manufacturing Simulation? Simulation Modelling Practice and Theory, 12, 515-526. http://dx.doi.org/10.1016/S1569-190X(03)00094-7

[15] Feghi Farahmand, N. (2011) Dynamic Management of Organization. 2nd Edition, Forouzesh Publication, Tabriz. (In Persian)

[16] Banks, J. and Carson, J. (2013) Simulation of Discrete-Event Systems. Mahlooji, H., Trans., 4th Edition, Scientific Publications of Sanati Sharif University, Tehran. (In Persian)

[17] Pinto, L.R., Silva, P.M.S. and Young, T.P. (2015) A Generic Method to Develop Simulation Models for Ambulance Systems. Journal of Simulation Modeling Practice and Theory, 51, 170-183. http://dx.doi.org/10.1016/j.simpat.2014.12.001

[18] Mourtzis, D., Doukas, M. and Bernidaki, D. (2014) Simulation in Manufacturing: Review and Challenges. Procedia CIRP, 25, 213-229. http://dx.doi.org/10.1016/j.procir.2014.10.032

[19] Ruiz, N., Giret, A., Botti, V. and Feria, V. (2014) An Intelligent Simulation Environment for Manufacturing Systems. 
Computers \& Industrial Engineering, 76, 148-168. http://dx.doi.org/10.1016/j.cie.2014.06.013

[20] Zhang, R., Chiang, W.-C. and Wu, C. (2014) Investigating the Impact of Operational Variables on Manufacturing Cost by Simulation Optimization. International Journal of Production Economics, 147, 634-646. http://dx.doi.org/10.1016/j.ijpe.2013.04.018

[21] Chongwatpol, J. and Sharda, R. (2013) RFID-Enabled Track and Traceability in Job-Shop Scheduling Environment. European Journal of Operational Research, 227, 453-463. http://dx.doi.org/10.1016/j.ejor.2013.01.009

[22] Roux, O., Duvivier, D., Quesnel, G. and Ramat, E. (2013) Optimization of Preventive Maintenance through a Combined Maintenance-Production Simulation Model. International Journal of Production Economics, 143, 3-12. http://dx.doi.org/10.1016/j.ijpe.2010.11.004

[23] Melouk, S.H., Freeman, N.K., Miller, D. and Dunning, M. (2013) Simulation Optimization-Based Decision Support Tool for Steel Manufacturing. International Journal of Production Economics, 141, 269-276. http://dx.doi.org/10.1016/j.ijpe.2012.08.001

[24] Huang, H.H., Pei, W., Wu, H.H. and May, M.D. (2013) A Research on Problems of Mixed-Line Production and the Re-Scheduling. Robotics and Computer-Integrated Manufacturing, 29, 64-72. http://dx.doi.org/10.1016/j.rcim.2012.04.014

[25] Altuntas, S. and Selim, H. (2012) Facility Layout Using Weighted Association Rule-Based Data Mining Algorithms: Evaluation with Simulation. Expert Systems with Applications, 39, 3-13. http://dx.doi.org/10.1016/j.eswa.2011.06.045

[26] Amiri, M. and Mohtashami, A. (2012) Buffer Allocation in Unreliable Production Lines Based on Design of Experiments, Simulation, and Genetic Algorithm. The International Journal of Advanced Manufacturing Technology, 62, 371-383. http://dx.doi.org/10.1007/s00170-011-3802-8

[27] Huang, C.J., Chang, K.H. and Lin, J.T. (2012) Optimal Vehicle Allocation for an Automated Materials Handling System Using Simulation Optimization. International Journal of Production Research, 50, 5734-5746. http://dx.doi.org/10.1080/00207543.2011.622311

[28] Dong, S. and Medeiros, D. (2012) Minimizing Schedule Cost via Simulation Optimization: An Application in Pipe Manufacturing. International Journal of Production Research, 50, 831-841. http://dx.doi.org/10.1080/00207543.2010.545447

[29] Ehrenberg, C. and Zimmermann, J. (2012) Simulation-Based Optimization in Make-to-Order Production: Scheduling for a Special-Purpose Glass Manufacturer. Proceedings of the 2012 Winter Simulation Conference, Berlin, 9-12 December 2012, 1-12. http://dx.doi.org/10.1109/WSC.2012.6465047

[30] Zhuo, L., Chua Kim Huat, D. and Wee, K.H. (2012) Scheduling Dynamic Block Assembly in Shipbuilding through Hybrid Simulation and Spatial Optimization. International Journal of Production Research, 50, 5986-6004. http://dx.doi.org/10.1080/00207543.2011.639816

[31] Felberbauer, T., Altendorfer, K. and Hubl, A. (2012) Using a Scalable Simulation Model to Evaluate the Performance of Production System Segmentation in a Combined MRP and Kanban System. Proceedings of the 2012 Winter Simulation Conference, Berlin, 9-12 December 2012, 1-12. http://dx.doi.org/10.1109/WSC.2012.6465053

[32] Mahfouz, A., Shea, J. and Arisha, A. (2011) Simulation Based Optimization Model for the Lean Assessment in SME: A Case Study. Proceedings of the 2011 Winter Simulation Conference, Phoenix, 11-14 December 2011, 2403-2413. http://dx.doi.org/10.1109/WSC.2011.6147950

[33] Angelidis, E., Pappert, F.S. and Rose, O. (2011) A Prototype Simulation Tool for a Framework for Simulation-Based Optimization of Assembly Lines. Proceedings of the 2011 Winter Simulation Conference, Phoenix, 11-14 December 2011, 2383-2394. http://dx.doi.org/10.1109/WSC.2011.6147948

[34] Porzucek, T., Kluth, S., Fritzsche, M. and Redlich, D. (2010) Combination of a Discrete Event Simulation and an Analytical Performance Analysis through Model-Transformations. IEEE International Conference on Engineering of Computer-Based Systems, Oxford, 22-26 March 2010, 183-192. http://dx.doi.org/10.1109/ecbs.2010.26

[35] Mahdavi, I., Shirazi, B. and Solimanpur, M. (2010) Development of a Simulation-Based Decision Support System for Controlling Stochastic Flexible Job Shop Manufacturing Systems. Simulation Modeling Practice and Theory, 18, 768786. http://dx.doi.org/10.1016/j.simpat.2010.01.015

[36] Savory, P. and Williams, R. (2010) Estimation of Cellular Manufacturing Cost Components Using Simulation and Activity-Based Costing. Journal of Industrial Engineering and Management, 3, 68-86. http://dx.doi.org/10.3926/jiem.2010.v3n1.p68-86

[37] Vasudevan, K., Lammers, E., Williams, E. and Ulgen, O. (2010) Application of Simulation to Design and Operation of Steel Mill Devoted to Manufacture of Line Pipes. 2nd International Conference on Advances in System Simulation (SIMUL), Nice, 22-27 August 2010, 1-6. http://dx.doi.org/10.1109/SIMUL.2010.11

[38] Jithavech, I. and Krishnan, K. (2010) A Simulation-Based Approach for Risk Assessment of Facility Layout Designs under Stochastic Product Demands. The International Journal of Advanced Manufacturing Technology, 49, 27-40. 
http://dx.doi.org/10.1007/s00170-009-2380-5

[39] Edis, R.S. and Ornek, A. (2009) Simulation Analysis of Lot Streaming in Job Shops with Transportation Queue Disciplines. Simulation Modeling Practice and Theory, 17, 442-453. http://dx.doi.org/10.1016/j.simpat.2008.10.002

[40] Um, I., Cheon, H. and Lee, H. (2009) The Simulation Design and Analysis of a Flexible Manufacturing System with Automated Guided Vehicle System. Journal of Manufacturing Systems, 28, 115-122. http://dx.doi.org/10.1016/j.jmsy.2010.06.001

[41] Nandagawe, S. and Sarmah, S.P. (2009) Development and Application of a Simulation Model for Throughput Improvement in the Melting Shop of a Steel Plant. International Journal of Operational Research, 6, 267-281. http://dx.doi.org/10.1504/IJOR.2009.026538

[42] Alfieri, A. (2009) Workload Simulation and Optimization in Multi-Criteria Hybrid Flow-Shop Scheduling: A Case Study. International Journal of Production Research, 47, 5129-5145. http://dx.doi.org/10.1080/00207540802010823

[43] Greasley, A. (2008) Using Simulation for Facility Design: A Case Study. Simulation Modeling Practice and Theory, 16, 670-677. http://dx.doi.org/10.1016/j.simpat.2008.04.009

[44] Habchi, G. and Berchet, C. (2003) A Model for Manufacturing Systems Simulation with a Control Dimension. Simulation Modeling Practice and Theory, 11, 21-44. http://dx.doi.org/10.1016/S1569-190X(02)00097-7

[45] Alamdari, S. (2013) Optimization of the Function of Abaadeh Fire Clay Mine Production System on the Basis of Simulation. Master's Thesis, Technical and Engineering School of Tarbiat Modares University, Tehran. (In Persian)

[46] Adl, M. (2011) Implementation of Discrete-Event Simulation in Reducing the Average Waiting Time of Customers in Queues (Case Study on Hyper Star Iran Shop). Master’s Thesis, Department of Industrial and Mechanical Engineering, Islamic Azad University of Qazvin, Qazvin. (In Persian)

[47] Shahrestani, M. (2011) Improvement in the Rate of Daily Production of a Snack Production Line Using the Two Strategies of Simulation and Genetics Algorithm. Master’s Thesis, Department of Industrial and Mechanical Engineering, Islamic Azad University of Qazvin, Qazvin. (In Persian)

[48] Syberfeldt, A. and Lidberg, S. (2012) Real-World Simulation-Based Manufacturing Optimization Using Cuckoo Search. Proceedings of the 2012 Winter Simulation Conference, 1-12. http://dx.doi.org/10.1109/WSC.2012.6465158

[49] Yang, T., Kuo, Y. and Chang, I. (2004) Tabu-Search Simulation Optimization Approach for Flow-Shop Scheduling with Multiple Processors-A Case Study. International Journal of Production Research, 42, 4015-4030. http://dx.doi.org/10.1080/00207540410001699381

[50] Deroussi, L., Gourgand, M. and Tchernev, N. (2006) Combining Optimization Methods and Discrete Event Simulation: A Case Study in Flexible Manufacturing Systems. International Conference on Service Systems and Service Management, 1, 495-500. http://dx.doi.org/10.1109/icsssm.2006.320512

[51] Li, J., Gonzlez, M. and Zhu, Y. (2009) A Hybrid Simulation Optimization Method for Production Planning of Dedicated Remanufacturing. International Journal of Production Economics, 117, 286-301. http://dx.doi.org/10.1016/j.ijpe.2008.11.005

[52] Eskandari, H., Rabelo, L. and Mollaghasemi, M. (2005) Multiobjective Simulation Optimization Using an Enhanced Genetic Algorithm. Proceedings of the 2005 Winter Simulation Conference, Orlando, 4-7 December 2005, 833-841. http://dx.doi.org/10.1109/WSC.2005.1574329

[53] Yang, T. (2009) An Evolutionary Simulation-Optimization Approach in Solving Parallel-Machine Scheduling Problems-A Case Study. Computers \& Industrial Engineering, 56, 1126-1136. http://dx.doi.org/10.1016/j.cie.2008.09.026

[54] Yang, T., Fu, H.P. and Yang, K.Y. (2007) An Evolutionary-Simulation Approach for the Optimization of Multi-Constant Work-in-Process Strategy-A Case Study. International Journal of Production Economics, 107, 104-114. http://dx.doi.org/10.1016/j.ijpe.2006.02.014

[55] Gong, J., Prabhu, V.V. and Liu, W. (2011) Simulation-Based Performance Comparison between Assembly Lines and Assembly Cells with Real-Time Distributed Arrival Time Control System. International Journal of Production Research, 49, 1241-1253. http://dx.doi.org/10.1080/00207543.2010.518733

[56] Wu, C.H., Lin, J.T. and Chien, W.C. (2012) Dynamic Production Control in Parallel Processing Systems under Process Queue Time Constraints. Computers \& Industrial Engineering, 63, 192-203. http://dx.doi.org/10.1016/j.cie.2012.02.003

[57] El-Bouri, A. (2012) A Cooperative Dispatching Approach for Minimizing Mean Tardiness in a Dynamic Flow Shop. Computers \& Operations Research, 39, 1305-1314. http://dx.doi.org/10.1016/j.cor.2011.07.004

[58] Weng, W. and Fujimura, S. (2012) Control Methods for Dynamic Time-Based Manufacturing under Customized Product Lead Times. European Journal of Operational Research, 218, 86-96. http://dx.doi.org/10.1016/j.ejor.2011.10.014

[59] Lu, H., Huang, G.Q. and Yang, H. (2011) Integrating Order Review/Release and Dispatching Rules for Assembly Job 
Shop Scheduling Using a Simulation Approach. International Journal of Production Research, 49, 647-669. http://dx.doi.org/10.1080/00207540903524490

[60] Mönch, L., Rose, O. and Sturm, R. (2003) A Simulation Framework for the Performance Assessment of Shop-Floor Control Systems. Simulation, 79, 163-170. http://dx.doi.org/10.1177/0037549703256039

[61] Joseph, O. and Sridharan, R. (2012) Effects of Flexibility and Scheduling Decisions on the Performance of an FMS: Simulation Modeling and Analysis. International Journal of Production Research, 50, 2058-2078. http://dx.doi.org/10.1080/00207543.2011.575091

[62] Joseph, O. and Sridharan, R. (2011) Analysis of Dynamic Due-Date Assignment Models in a Flexible Manufacturing System. Journal of Manufacturing Systems, 30, 28-40. http://dx.doi.org/10.1016/j.jmsy.2011.02.005

[63] Vinod, V. and Sridharan, R. (2011) Simulation Modeling and Analysis of Due-Date Assignment Methods and Scheduling Decision Rules in a Dynamic Job Shop Production System. International Journal of Production Economics, 129, 127-146. http://dx.doi.org/10.1016/j.ijpe.2010.08.017

[64] Chan, F.T.S. and Chan, H.K. (2004) Analysis of Dynamic Control Strategies of an FMS under Different Scenarios. Robotics and Computer-Integrated Manufacturing, 20, 423-437. http://dx.doi.org/10.1016/j.rcim.2004.03.005

[65] Tyan, J.C., Chen, J.C. and Wang, F.K. (2002) Development of a State-Dependent Dispatch Rule Using Theory of Constraints in Near-Real-World Wafer Fabrication. Production Planning \& Control, 13, 253-261. http://dx.doi.org/10.1080/09537280110070278

[66] Kumar, S.N. and Sridharan, R. (2007) Simulation Modeling and Analysis of Tool Sharing and Part Scheduling Decisions in Single-Stage Multi Machine Flexible Manufacturing Systems. Robotics and Computer-Integrated Manufacturing, 23, 361-370. http://dx.doi.org/10.1016/j.rcim.2006.02.013

[67] Marashi, S.N. (2007) Evaluation of Work and Time. 5th Edition, Kaarafarinan Basir Publication, Tehran. (In Persian)

[68] Aazar, A. and Momeni, M. (2008) Statistics and Its Usage in Management. 11th Edition, Vol. 1 \& 2, SAMT Publication, Tehran. (In Persian)

[69] Mottagi, H. (2009) Production and Operation Management. 7th Edition, Aavayeh Patris Publication, Tehran. (In Persian) 


\section{Appendix}

Table A1. Summary report 1.

\begin{tabular}{|c|c|c|c|c|c|c|}
\hline \multirow[b]{2}{*}{ Name } & \multirow[t]{2}{*}{ Content } & \multicolumn{2}{|c|}{ Throughput } & \multicolumn{2}{|c|}{ Staytime } & \multirow[b]{2}{*}{ Average } \\
\hline & & Current & Average & Input & Output & \\
\hline 1 & & 1 & 1.000 & 1113 & 1112 & 21.030 \\
\hline 2 & & 1 & 0.929 & 564 & 563 & 38.532 \\
\hline 3 & & 1 & 0.930 & 596 & 595 & 36.519 \\
\hline \multirow[t]{2}{*}{4} & & 1 & 0.991 & 595 & 594 & 38.990 \\
\hline & Pinch rol & 0 & 0.270 & 594 & 594 & 10.631 \\
\hline 5 & & 0 & 0.331 & 555 & 555 & 13.963 \\
\hline 6 & & 0 & 0.559 & 524 & 524 & 24.941 \\
\hline 7 & & 1 & 0.664 & 503 & 502 & 30.932 \\
\hline 8 & & 1 & 0.787 & 472 & 471 & 39.082 \\
\hline 9 & & 1 & 0.945 & 471 & 470 & 47.036 \\
\hline 10 & & 1 & 0.179 & 470 & 469 & 8.921 \\
\hline \multirow[t]{2}{*}{11} & & 0 & 0.369 & 469 & 469 & 18.418 \\
\hline & Role & 0 & 0.226 & 469 & 469 & 11.264 \\
\hline 12 & & 1 & 0.419 & 469 & 468 & 20.968 \\
\hline 13 & & 0 & 0.393 & 468 & 468 & 19.659 \\
\hline 14 & & 0 & 0.000 & 117 & 0 & 0.000 \\
\hline \multicolumn{7}{|c|}{ Run length (seconds) 23400.00} \\
\hline End of repor & & & & & & \\
\hline
\end{tabular}

Table A2. Summary report 2.

\begin{tabular}{|c|c|c|c|c|c|c|}
\hline \multirow[b]{2}{*}{ Name } & \multirow[t]{2}{*}{ Content } & \multicolumn{2}{|c|}{ Throughput } & \multicolumn{2}{|c|}{ Staytime } & \multirow[b]{2}{*}{ Average } \\
\hline & & Current & Average & Input & Output & \\
\hline 1 & & 1 & 1.000 & 1198 & 1197 & 21.046 \\
\hline 2 & & 1 & 0.937 & 692 & 691 & 34.137 \\
\hline 3 & & 0 & 0.637 & 918 & 918 & 17.474 \\
\hline 4 & & 1 & 0.998 & 645 & 644 & 38.990 \\
\hline & Pinch Rol & 0 & 0.256 & 644 & 644 & 10.000 \\
\hline 5 & & 1 & 0.282 & 629 & 628 & 11.293 \\
\hline 6 & & 0 & 0.437 & 615 & 615 & 17.922 \\
\hline 7 & & 0 & 0.434 & 607 & 607 & 18.020 \\
\hline 8 & & 0 & 0.284 & 600 & 600 & 11.922 \\
\hline 9 & & 1 & 0.538 & 289 & 288 & 47.056 \\
\hline & Copy of 9 & 1 & 0.580 & 311 & 310 & 47.033 \\
\hline 10 & & 0 & 0.249 & 598 & 598 & 10.485 \\
\hline 11 & & 1 & 0.456 & 598 & 597 & 19.236 \\
\hline & Role & 0 & 0.322 & 597 & 597 & 13.599 \\
\hline 12 & & 0 & 0.504 & 597 & 597 & 21.281 \\
\hline 13 & & 0 & 0.481 & 597 & 597 & 20.322 \\
\hline 14 & & 0 & 0.000 & 61 & 0 & 0.000 \\
\hline
\end{tabular}


Table B1. Overhead crane (No. 1).

$\begin{array}{cc}\text { Distribution } & \text { Parameters } \\ \text { Normal } & \mathrm{s}=1 / 7 \mathrm{~m}=21 / 0\end{array}$

Table B2. Bullion shearing machine.

$\begin{array}{cc}\text { Distribution } & \text { Parameters } \\ \text { Uniform } & \mathrm{a}=30 / 0 \mathrm{~b}=35 / 0\end{array}$

Table B3. Overhead crane (No. 2).

\begin{tabular}{cc|}
\hline Distribution & Parameters \\
\hline Uniform & $\mathrm{a}=15 / 0 \mathrm{~b}=20 / 0$ \\
\hline
\end{tabular}

Table B4. Furnace (3 steps).

\begin{tabular}{cc}
\hline Distribution & Parameters \\
\hline Triangular & $m=39 / 0 \mathrm{a}=37 / 0 \mathrm{~b}=40 / 0$
\end{tabular}

Table B5. Rolling (step 1).

\begin{tabular}{cc} 
Distribution & Parameters \\
\hline Beta & $\begin{array}{c}\mathrm{a}_{1}=0 / 64 \mathrm{a}_{2}=0 / 85 \\
\mathrm{a}=10 / 0 \mathrm{~b}=12 / 0\end{array}$ \\
\hline
\end{tabular}

Table B6. Rolling (step 2).

\section{Distribution}

Beta

\section{Parameters}

$\mathrm{a}_{1}=0 / 74 \mathrm{a}_{2}=0 / 78$

$\mathrm{a}=15 / 0 \mathrm{~b}=18 / 0$

Table B7. Rolling (step 3).

\section{Distribution}

Triangular

\section{Parameters}

$\mathrm{m}=18 / 0 \mathrm{a}=17 / 0 \mathrm{~b}=20 / 0$

Table B8. Overhead crane (No. 3).

\begin{tabular}{cc}
\hline Distribution & Parameters \\
\hline Weibull & $\mathrm{a}=12 / 0 \mathrm{~b}=9 / 8$ \\
\hline
\end{tabular}

Table B9. Cooling bed.

\begin{tabular}{cc}
\hline Distribution & Parameters \\
\hline Triangular & $\mathrm{m}=47 / 0 \mathrm{a}=45 / 0 \mathrm{~b}=48 / 0$ \\
\hline & \\
\hline Table B10. Electric cold use scissors. & Parameters \\
\hline Distribution & $\mathrm{s}=0 / 73 \mathrm{~m}=8 / 9$ \\
\hline Normal &
\end{tabular}


A. A. Saidabad, H. Taghizadeh

Table B11. Packing.

Distribution

Beta

Table B12. Overhead crane (No. 4).

\begin{tabular}{cc}
\hline Distribution & Parameters \\
\hline Beta & $\begin{array}{c}\mathrm{a}_{1}=1 / 2 \mathrm{a}_{2}=1 / 5 \\
\mathrm{a}=17 / 0 \mathrm{~b}=24 / 0\end{array}$ \\
\hline Table B13. Overhead crane (No. 5). & \\
\hline Distribution & Parameters \\
\hline Beta & $\begin{array}{l}\mathrm{a}_{1}=1 / 1 \mathrm{a}_{2}=0 / 88 \\
\mathrm{a}=18 / 0 \mathrm{~b}=23 / 0\end{array}$ \\
\hline
\end{tabular}

\section{Parameters}

$\mathrm{a}_{1}=0 / 67 \mathrm{a}_{2}=0 / 65$

$\mathrm{a}=17 / 0 \mathrm{~b}=21 / 0$

$\mathrm{a}=18 / 0 \mathrm{~b}=23 / 0$ 